\title{
A Comparative Study of (Poly)ether Adducts of Alkaline Earth Iodides - An Overview Including New Compounds
}

\author{
William Maudez ${ }^{[a]}$ and Katharina M. Fromm*[b]
}

Keywords: Alkaline earth metals; Polyethers; Tetrahydrofuran; Solid state structure

\begin{abstract}
New homoligand and mixed-ligand adducts of the heavier alkaline earth metal $(\mathrm{Ca}, \mathrm{Sr}, \mathrm{Ba})$ halides with oxygen-donor polyether ligands have been isolated and characterized and are compared with previously obtained compounds of the same class in order to give an overview on structures and properties. Homoligand halide adducts, discussed herein, are $\left[\mathrm{CaI}(\mathrm{DME})_{3}\right] \mathrm{I}(\mathbf{1})$, trans $-\left[\mathrm{SrI}_{2}(\mathrm{DME})_{3}\right](\mathbf{2})$, trans$\left[\mathrm{BaI}_{2}(\mathrm{DME})_{3}\right](\mathbf{3}),(\mathrm{DME}=$ ethylene glycol dimethyl ether), [CaI(diglyme $\left.)_{2}\right] \mathrm{I}$ (4), cis- $\left.\left[\mathrm{SrI}_{2} \text { (diglyme) }\right)_{2}\right]$ (5), trans-[BaI ${ }_{2}$ diglyme $\left.)_{2}\right]$ (6), $\left(\right.$ diglyme $=$ diethylene glycol dimethyl ether, $\left[\operatorname{SrI}(\text { triglyme })_{2}\right] \mathrm{I}(7)$, and $\left[\mathrm{BaI}(\text { triglyme })_{2}\right] \mathrm{I}(\mathbf{8})$, (triglyme = triethylene glycol dimethyl ether).
\end{abstract}

Introduction of the mono-coordinating THF ligand $(\mathrm{THF}=$ tetrahydrofuran) in the coordination sphere of 1, 2, 3, 4 allows the formation of the new mixed-ligand compounds trans-[CaI $\left.{ }_{2}(\mathrm{DME})_{2}(\mathrm{THF})\right]$ (9), trans- $\left[\mathrm{SrI}_{2}(\mathrm{DME})_{2}(\mathrm{THF})\right](\mathbf{1 0})$, trans-[BaI $\left.{ }_{2}(\mathrm{DME})_{2}(\mathrm{THF})_{2}\right]$ (11), and trans- $\left[\mathrm{CaI}_{2}(\text { diglyme })_{2}(\mathrm{THF})_{2}\right](\mathbf{1 2})$. These compounds were obtained from the metal halide salts in solution with pure or mixtures of ether solvents. While compounds 1-8 appear to be very stable and non-reactive, adducts 9-12 present a comparable reactivity to the well known THF adducts $\left[\mathrm{MI}_{2}(\mathrm{thf})_{n}\right](\mathrm{M}=\mathrm{Ca}, n=4$; $\mathrm{Sr}, \mathrm{Ba}, n=5)$.

\section{Introduction}

The coordination chemistry of the heavier Group 2 metals $(\mathrm{Ca}, \mathrm{Sr}, \mathrm{Ba})$ is of interest as a large variety of molecular or low-dimensional polymeric compounds, i.e, clusters, may be used as precursors to superconductors in CVD or sol-gel processes, ${ }^{[1]}$ in synthetic chemistry, ${ }^{[2]}$ and in organometallic synthesis with potential applications in catalysis. ${ }^{[3]}$ Among synthetic routes used for the preparation of such alkaline earth metal derivatives, alkane/arene elimination, transamination, direct metalation, and transmetalation are dependent of the availability of the starting materials and some intrinsic properties of the ligands such as their $\mathrm{pK}_{\mathrm{a}}$-values. This explains why the well established salt elimination route has become the most commonly synthetic strategy used in the s-block chemistry. One of the major problems of the synthesis of organo- alkaline earth metal compounds is their possible tendency to form insoluble polymers, ${ }^{[1,4]}$ on one hand due to their low metal oxidation state $\mathrm{M}^{\mathrm{II}}$, which only allows two anionic ligands, and on the other hand, their large ionic radii, which demand a high coordination number. A parry to prevent a high degree of oligomerization is the use of neutral Lewis-coordinating ligands such as monodentate THF or multidentate polyether (or

\footnotetext{
* Prof. Dr. K. M. Fromm

Fax: +41-26-300-9738

E-Mail: katharina.fromm@unifr.ch

[a] LSPM-CNRS

Université Paris 13

99 Avenue Jean Baptiste Clément

93430 Villetaneuse, France

[b] Department of Chemistry

University of Fribourg

Chemin du musée, 9

1700 Fribourg, Switzerland
}

glyme) ligands, which avoid any further "metal-metal contacts" via bridging ligands, saturating the metal cation.

The salt metathesis route involves metal halides or pseudohalides as metal sources. Typically, $\mathrm{MI}_{2}$-salts are employed due to their higher solubility in weak polar organic solvents; however starting materials are often restricted to the THF-adducts due to their easy preparation and reactivity. They are commonly used for substitution reactions of at least one iodide. So the chemistry of metal halide or pseudo-halide adducts with neutral Lewis-coordinating ligands (usually non-polar aprotic solvents) is still not systematically studied, while their synthesis and characterization appear to be a useful endeavor. In the class of monomeric compounds, only few adducts of the heavier group 2 metal halides have been reported. Covalent species of the type $\mathrm{MX}_{2}$ \{Ligands $\}$ ( $\mathrm{X}=$ halides) are the zero-dimensional compounds trans-[ $\left.\mathrm{MI}_{2}(\mathrm{THF})_{n}\right]\left(\mathrm{M}=\mathrm{Ca},{ }^{[5]} \mathrm{Sr},{ }^{[6]} \mathrm{Ba} ;{ }^{[7]}\right.$ $\mathrm{THF}=$ tetrahydrofuran $),$ trans $-\left[\mathrm{SrI}_{2}(\mathrm{DME})_{3}\right],{ }^{[8]}$ trans$\left[\mathrm{BaI}_{2}(\mathrm{DME})_{3}\right]^{[9]}(\mathrm{DME}=$ ethylene glycol dimethyl ether, 1,2-dimethoxyethane), trans- $\left[\mathrm{CaI}_{2}(\mathrm{DME})_{2}(\mathrm{THF})\right],{ }^{[10]}$ trans$\left.\left[\mathrm{CaI}_{2} \text { (diglyme)(thf) }\right)_{2}\right],{ }^{[11]}$ trans $-\left[\mathrm{CaI}_{2} \text { (diglyme) }(\mathrm{DME})\right]^{[12]}$ (diglyme = diethylene glycol dimethyl ether), and trans $-\left[\mathrm{BaI}_{2}\right.$ (triglyme $)(\mathrm{DME})]^{[9]}$ (triglyme = triethylene glycol dimethyl ether). In these molecular compounds, the metal cation is always surrounded in linear or quasi-linear fashion by the two iodide anions. Only two cis-compound, cis-[BaI 2 (DME)(tetraglyme) (tetraglyme $=$ tetraethylene glycol dimethyl ether) and $c i s-\left[\mathrm{SrI}_{2}(\text { diglyme })_{2}\right]$ have been described previously. ${ }^{[9,13]}$ In some cases, halide ions are replaced in the first coordination sphere of the metal atom by polyether oxygen donor ligands for instance, leading to ionic compounds of the type $[\mathrm{MX}\{$ ligands $\}] \mathrm{X}$ or $[\mathrm{M}\{$ ligands $)] \mathrm{X}_{2}$ such as $\left[\mathrm{CaI}(\mathrm{DME})_{3}\right] \mathrm{I},{ }^{[13]}$ $\left[\mathrm{CaI}(\text { diglyme })_{2}\right] \mathrm{I},{ }^{[14]}$ or $\left[\mathrm{Ba}(\text { tetraglyme })_{2}\right] \mathrm{I}_{2} \cdot \mathrm{C}_{7} \mathrm{H}_{8} \cdot{ }^{[9]}$ All these 
covalent or ionic adducts are monomeric, mainly because of the absence of water in their coordination sphere. ${ }^{[7 a]}$ Indeed, in the latter case, it has been shown by the author's group that the number of water molecules coordinated to the alkaline earth metals controls their dimensionality, iodide anions being linked to the cationic complexes by hydrogen bonding. Reactions of $\mathrm{MI}_{2}$ and glymes containing $<5 \%$ water affords 0D-, 1D-, 2D- and 3D-polymers, respectively $\left.\left[\mathrm{BaI}_{2} \text { (triglyme }\right)_{2}\left(\mathrm{H}_{2} \mathrm{O}\right)\right], \quad\left[\mathrm{M}(\text { diglyme })_{2}\left(\mathrm{H}_{2} \mathrm{O}\right)_{x}\right] \mathrm{I}_{2}, \quad(\mathrm{M}=\mathrm{Ca}$, $x=2 ; \mathrm{M}=\mathrm{Ba}, x=3)$ and $[\mathrm{Ca}$ (triglyme $\left.)\left(\mathrm{H}_{2} \mathrm{O}\right)_{4}\right] \mathrm{I}_{2} \cdot{ }^{[15]}$

In this context, we now present some water-free, molecular homoligand and mixed-ligand group 2 metal halide adducts using monodentate and polydentate neutral Lewis-coordinating ligands such as THF $\left(\mathrm{C}_{4} \mathrm{H}_{8} \mathrm{O}\right)$, DME $\left(\mathrm{CH}_{3} \mathrm{OC}_{2} \mathrm{H}_{4} \mathrm{OCH}_{3}\right)$, diglyme $\left(\mathrm{CH}_{3}\left(\mathrm{OC}_{2} \mathrm{H}_{4}\right)_{2} \mathrm{OCH}_{3}\right)$ and triglyme $\left(\mathrm{CH}_{3}\left(\mathrm{OC}_{2} \mathrm{H}_{4}\right)_{3}-\right.$ $\mathrm{OCH}_{3}$ ) in order to, in a fundamental way, know and understand better the chemistry of $s$-block metal halides in aprotic solvents. We give an overview on the existing adducts, including literature known as well as new compounds. Secondly, we were interested in the study of the influence of the size of the ligand on the coordination sphere of the metal cation using monodentate and polydentate O-donor ligands. Finally, we wanted to compare the reactivity of the polydentate polyethercontaining molecular compounds with the THF adduct ones.

\section{Results and Discussion}

The first three title species $\left[\mathrm{CaI}(\mathrm{DME})_{3}\right] \mathrm{I} \quad(\mathbf{1}){ }^{[13]}$ $\left[\mathrm{SrI}_{2}(\mathrm{DME})_{3}\right](\mathbf{2}){ }^{[8]}$ and $\left[\mathrm{BaI}_{2}(\mathrm{DME})_{3}\right](\mathbf{3})^{[9]}$ have already been reported. Whilst $\mathbf{1}$ was reported by the author's group, $\mathbf{2}$ was obtained by Weber et al. using ammonia activation, and $\mathbf{3}$ was described by Mishra et al. from the redistribution reaction of $\mathrm{NaBaI}_{2}(\mathrm{HFIP})\left(\mathrm{H}_{2} \mathrm{O}\right)(\mathrm{THF})_{0.5}\left(\mathrm{HFIP}=\mathrm{OCH}\left(\mathrm{CF}_{3}\right)_{2}\right)$ in a THF/DME mixture, but for $\mathbf{3}$ no crystal structure was given. $\mathbf{1}, \mathbf{2}$, and $\mathbf{3}$ can easily be obtained directly by dissolving anhydrous $\mathrm{AeI}_{2}(\mathrm{Ae}=\mathrm{Ca}, \mathrm{Sr}, \mathrm{Ba})$ in hot DME. In an earlier paper, the author's group reported the synthesis of the compound $\mathrm{Li}\left[\left\{\mathrm{Ca}_{7}\left(\mu_{3}-\mathrm{OH}\right)_{8} \mathrm{I}_{6}(\mathrm{THF})_{12}\right\}_{2}(\mu-\mathrm{I})\right] \cdot 3 \mathrm{THF}$ by reaction of $\left[\mathrm{CaI}_{2}(\mathrm{THF})_{4}\right]$ with $n \mathrm{BuLi}^{[1 \mathrm{ff}]} \mathrm{In}$ order to study the behavior and reactivity of $\left[\mathrm{CaI}(\mathrm{DME})_{3}\right] \mathrm{I}, \mathbf{1}$ was treated in a similar manner but no reaction occurred resulting in the recrystallization of the compound $\left[\mathrm{CaI}(\mathrm{DME})_{3}\right] \mathrm{I} \mathbf{1}$. Suitable crystals of $\mathbf{1}, \mathbf{2}$, and $\mathbf{3}$ were obtained from the reaction media.

Crystal structures of $\mathbf{1}$ and $\mathbf{2}$ are known and will thus only be shortly described here. However, for the first time, the crystal structure of trans-[BaI $\left.{ }_{2}(\mathrm{DME})_{3}\right](3)$ is presented. These three homoligand species are monomeric in the solid state and clearly show the influence of the ionic radii of the alkaline earth metal centre on their molecular structures. A comparison of the DME adducts $\mathbf{1}, \mathbf{2}$, and $\mathbf{3}$ is given in Table 1 .

Compound $\mathbf{1}$, crystallizing in $P 2_{1} / n$, has two independent cationic molecules A and B per asymmetric unit. The calcium atoms are coordinated by five oxygen atoms of DME ligands, lying approximately in a plane, and one remaining oxygen atom of DME and an iodide in axial positions (Figure 1). This gives rise to cationic, distorted pentagonal bipyramidal species, with iodide as separate anions.
Table 1. Comparison of bond lengths and angles of the DME adducts $\mathbf{1}, \mathbf{2}$, and $\mathbf{3}$

\begin{tabular}{llll}
\hline Compound & $\mathbf{1}$ & $\mathbf{2}$ & $\mathbf{3}$ \\
\hline $\mathrm{M}-\mathrm{I} / \AA$ (av.) & $3.120(5)$ & $3.398(5)$ & $3.479(1)$ \\
$\mathrm{I}-\mathrm{M}-\mathrm{I} /{ }^{\circ}$ & & $158.69(2)$ & $170.251(14)$ \\
$\mathrm{M}-\mathrm{O} / \AA$ (av.) & $2.423(2)$ & $2.644(5)$ & $2.821(3)$ \\
$\mathrm{O}-\mathrm{M}-\mathrm{O} /{ }^{\circ}$ (av.) & $66.71(7)$ & $61.57(7)$ & $58.04(3)$ \\
\hline
\end{tabular}

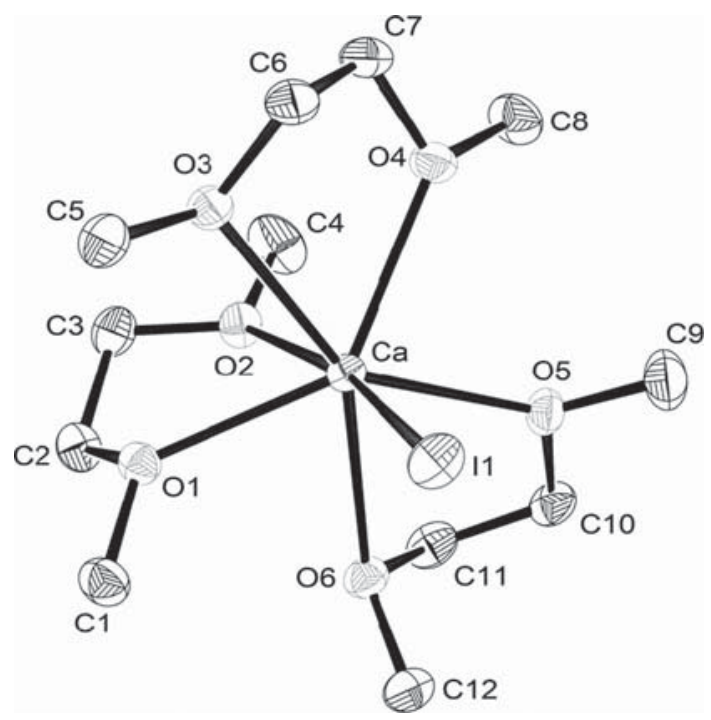

Figure 1. View of the cationic structure unit $\left[\mathrm{CaI}(\mathrm{dme})_{3}\right]^{+}$of molecule A in 1, hydrogen atoms are omitted for clarity, $30 \%$ probability.

The corresponding I1-Ca-O2 angle in $\mathbf{1}$ is with $154.5(3)^{\circ}$ far from linear, principally due to the bite angles of the DME ligands $\left(63.7(4)\right.$ to $\left.68.8(3)^{\circ}\right)$. The $\mathrm{Ca}-\mathrm{O}$ distances are on average 2.423(2) $\AA$ long, and the $\mathrm{Ca}-\mathrm{I}$ is 3.120(3) $\AA$. The Ca.*I distance to the free anion in $\mathbf{1}$ is greater than $5.8 \AA$.

With a larger ionic radii, the strontium metal cation in $\mathbf{2}$, trans- $\left[\mathrm{SrI}_{2}(\mathrm{DME})_{3}\right]$, allows the coordination of three DME molecules in a propeller-like fashion and two iodide anions without $\mathrm{Sr}-\mathrm{I}$ bonds cleavage leading to a neutral molecular species (Figure 2). ${ }^{[8]}$ The coordination sphere of strontium can thus be described as a distorted hexagonal bipyramid with the two anions in axial positions. The average $\mathrm{Sr}-\mathrm{I}$ and $\mathrm{Sr}-\mathrm{O}$ distances as well as the I-Sr-I angle are of values of 3.398(5) $\AA$, 2.643(5) $\AA$ and $158.69(2)^{\circ}$ respectively. Due to similar ionic $\operatorname{radii}\left(r_{\mathrm{Sr}}{ }^{2+}=1.26 \AA, r_{\mathrm{Eu}}{ }^{2+}=1.25 \AA, r_{\mathrm{Sm}}{ }^{2+}=1.27 \AA\right)^{[16]}$ the structure of $\mathbf{2}$ can be related to the reported europium(II) and samarium(II) compounds trans $-\left[\mathrm{LnI}_{2}(\mathrm{DME})_{3}\right] .{ }^{[17]}$

The last homoligand DME adduct trans- $\left[\mathrm{BaI}_{2}(\mathrm{DME})_{3}\right](3)$, which crystallizes in monoclinic $C 2 / c$, has a similar crystal structure to $\mathbf{2}$ (as it is observed for the THF adducts) where the barium cation is surrounded by the six oxygen atoms of the three DME ligands in an approximate plane and the two iodide ions in trans position, displaying a distorted hexagonal bipyramidal geometry (Figure 3 ). The average Ba-I distances of 3.479(1) $\AA$ are longer than previously observed $\mathrm{Ba}-\mathrm{I}$ bonds lengths in other molecular barium iodide adducts with $\mathrm{CN}=$ $7^{[7]}$ and shorter than those in molecular barium iodide adducts with $\mathrm{CN}=8$, independent of the $\mathrm{I}-\mathrm{Ba}-\mathrm{I}$ angle (cis or trans 


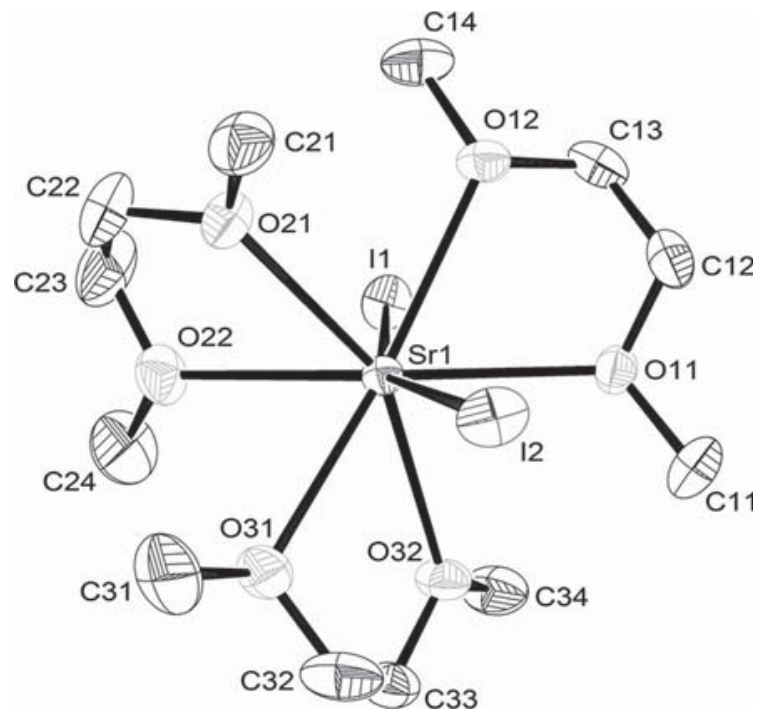

Figure 2. View of the molecular structure of 2, hydrogen atoms are omitted for clarity, $30 \%$ probability.

compounds). ${ }^{[18]}$ Oxygen atoms of DME ligands are coordinated to the barium ion with distances ranging between 2.802(4) and 2.852(3) A. The formal replacement of two DME molecules by the larger triglyme molecule affords $\left[\mathrm{BaI}_{2}(\mathrm{dme})\right.$ (triglyme)]. ${ }^{[9]}$ This results in less steric repulsions between the $\mathrm{O}$-donor ligands, the observed $\mathrm{Ba}-\mathrm{I}$ distance of $3.441(5) \AA$ is thus smaller than in 3 . The I-Ba-I angle is slightly different from linear with a value of $170.251(14)^{\circ}$ probably due to steric repulsions between the three DME ligands; but it is closer to linear than the one observed in $\mathbf{2}$ and $\left[\mathrm{BaI}_{2}(\mathrm{dme})(\right.$ triglyme$\left.)\right]$, the triglyme ligand shielding one face of the barium atom in the latter.

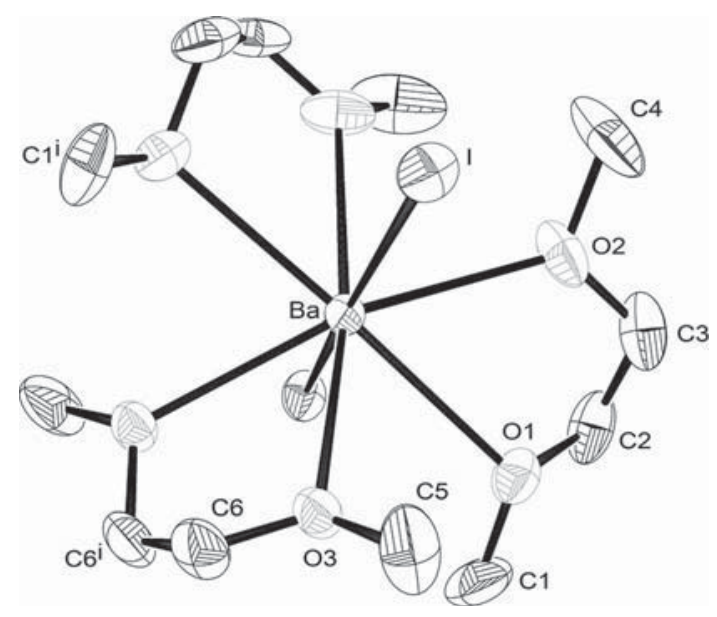

Figure 3. View of the molecular structure of $\mathbf{3}$, hydrogen atoms are omitted for clarity, $30 \%$ probability.

It has been demonstrated that small polyether molecules (such as DME) may easily be replaced by larger ones (diglyme or triglyme for instance) if no changes in the structure occur, except for possible higher symmetries, and thus as long as the number of oxygen atoms remains constant. ${ }^{[15 b]}$ This was con- firmed above ( 3 and $\left[\mathrm{BaI}_{2}(\mathrm{dme})(\right.$ triglyme $\left.)\right]$ ) and was studied in the following compounds.

Replacement of DME with the larger diglyme affords the alkaline earth iodide adducts $\left[\mathrm{CaI}(\text { diglyme })_{2}\right] \mathrm{I}$ (4), $\left[\mathrm{SrI}_{2}(\mathrm{di}-\right.$ glyme $\left.)_{2}\right]$ (5) and $\left[\mathrm{BaI}_{2}(\text { diglyme })_{2}\right](\mathbf{6})$. The author's group has already reported 4 in a private communication due to poor single-crystal data and $\mathbf{5},{ }^{[13,14]}$ which will be shortly described here, while $\mathbf{6}$ is new in this series. A comparison of $\mathbf{4 , 5}$, and $\mathbf{6}$ is given in Table 2.

Table 2. Comparison of bond lengths and angles of diglyme adducts 4,5 , and 6 .

\begin{tabular}{llll}
\hline Compound & $\mathbf{4}$ & $\mathbf{5}$ & $\mathbf{6}$ \\
\hline $\mathrm{M}-\mathrm{I} / \AA$ & $3.106(7)$ & $3.325(8)$ & $3.416(9)$ \\
$\mathrm{I}-\mathrm{M}-\mathrm{I} /{ }^{\circ}$ & & $91.51(5)$ & 180 \\
$\mathrm{M}-\mathrm{O} / \AA$ & $2.42(3)$ & $2.659(8)$ & $2.817(4)$ \\
$\mathrm{O}-\mathrm{M}-\mathrm{O} /{ }^{\circ}$ & $65.92(3)$ & $60.03(8)$ & $57.20(8)$ \\
\hline
\end{tabular}

By formally replacing the three DME ligands by two larger diglyme molecules $\left(\mathrm{CH}_{3} \mathrm{O}\left(\mathrm{C}_{2} \mathrm{H}_{4} \mathrm{O}\right)_{2} \mathrm{CH}_{3}\right)$, a similar compound to 1 can be obtained, namely [CaI(diglyme) $\left.)_{2}\right] \mathrm{I}$ (4) (Figure 4). As expected, the total number of six coordinating $\mathrm{O}$-atoms remains identical, and so does their arrangement around the cation. The calcium cation is thus surrounded by two diglyme ligands and one iodide anion, the second iodide anion being "free" as observed for compound 1. ${ }^{[14]}$

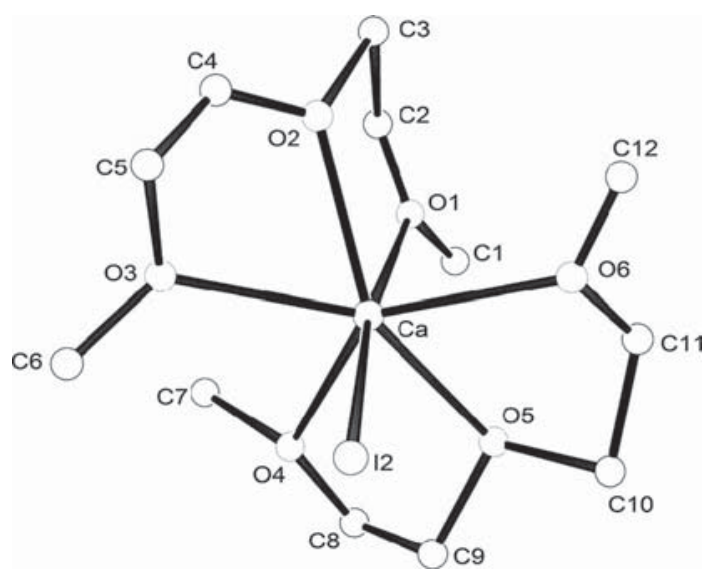

Figure 4. View of the cationic structure unit $\left[\mathrm{CaI}(\text { diglyme })_{2}\right]^{+}$of $\mathbf{4}$, Thermal ellipsoids are not shown due to bad quality of the crystal.

The $\mathrm{Ca}-\mathrm{O}$ (average $2.42(3) \AA$ ) as well as the $\mathrm{Ca}-\mathrm{I}$ bond lengths, 3.106(7) $\AA$, are slightly shorter in $\mathbf{4}$ than in $\mathbf{1}$ but this can be easily understood by the relative bulkiness of the three DME vs. two diglyme ligands. The two terminal methylgroups of the DME ligands are formally replaced by one smaller ethyl-group in diglyme. Two larger ligands such as diglyme have fewer degrees of freedom than three DME molecules, and steric repulsions imposed between the three less bulky DME ligands are stronger than those with two larger diglyme ligands around the calcium atom. This results in longer $\mathrm{Ca}-\mathrm{X}(\mathrm{X}=\mathrm{O}$, I) bond lengths in $\mathbf{1}$.

As diglyme adduct of $\mathrm{SrI}_{2}$, only the compound cis- $\left[\mathrm{SrI}_{2}(\mathrm{di}-\right.$ glyme $)_{2}$ ] (5) is obtained, with two very similar, but independent molecules A and B per asymmetric unit. ${ }^{[13]}$ In contrast to 
$\mathbf{1}$ and $\mathbf{4}$, the replacement of three DME coordinating molecules in $\mathbf{2}$ by two diglyme molecules in $\mathbf{5}$ shows strong effects (Figure 5). Indeed, The I-Sr-I angle decreases from 158.73(3) ${ }^{\circ}$ in 2 to $91.51(5)^{\circ}$ on average in $5\left(\mathrm{~A}: 91.25(9)^{\circ}, \mathrm{B}: 91.78(9)^{\circ}\right)$, both anions being in vicinal positions. Thus, due to repulsions between iodide anions, the $\mathrm{Sr}-\mathrm{I}$ bond lengths increase to on average $3.325 \AA$, accompanied with a decrease in $\mathrm{Sr}-\mathrm{O}$ bond lengths (average $2.660 \AA$ ). An interesting comparison is the samarium compounds, cis- $\left[\mathrm{SmI}_{2}(\text { diglyme })_{2}\right]$ and trans- $\left[\mathrm{SmI}_{2}(\mathrm{di}-\right.$ glyme $)_{2}$ ], which have actually been isolated both from the same solution. ${ }^{[19]}$ The former compound presents a similar geometry, bond lengths and angle values as observed for $\mathbf{2}$. A trans-Sr-compound was however never isolated in our laboratories, yet we cannot exclude its existence.

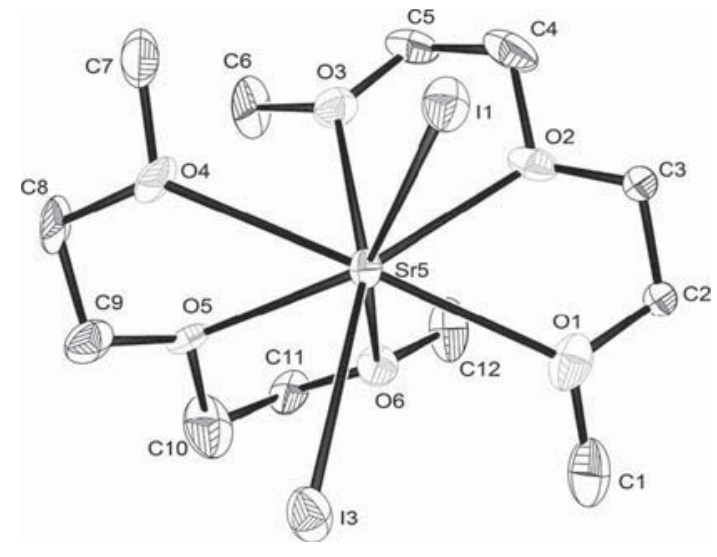

Figure 5. View of the molecular structure of molecule A in 5, hydrogen atoms are omitted for clarity, $30 \%$ probability.

Finally, reaction of $\mathrm{BaI}_{2}$ with diglyme afforded the new trans- $\left.\left[\mathrm{BaI}_{2} \text { (diglyme) }\right)_{2}\right]$ (6) (Figure 6). Compound $\mathbf{6}$ crystallizes in the triclinic space group $P \overline{1}$ with two independent molecules $\mathrm{A}$ and $\mathrm{B}$ per asymmetric unit. In each molecule, the barium atoms are octacoordinated in a distorted hexagonal bipyramidal geometry. The six oxygen atoms from the two diglyme ligands, with distances ranging between 2.793(9) and 2.835(3) $\AA$, form a distorted hexagon with the central oxygen atom of each diglyme ligand being slightly tilted out of the equatorial plane. The two iodide ions are in trans-positions to each other, with Ba-I distances of 3.414(3) and 3.419(4) A. The I-Ba-I angle is perfectly linear due to inversion centers on which the barium cations are located (Ba1 1/2, 0, 1/2 (f); $\mathrm{Ba} 2$ 0, -1/2, 0 (c)). Here again, the decrease in steric repulsions between the two larger O-donor ligands lead to smaller $\mathrm{Ba}-\mathrm{X}(\mathrm{X}=\mathrm{O}, \mathrm{I})$ bond lengths in $\mathbf{6}$ as compared to $\mathbf{3}$.

Again, a comparison with trans- $\left[\mathrm{BaI}_{2}(\mathrm{dme})(\text { triglyme })\right]^{[9]}$ is interesting as the number of $\mathrm{O}$-atoms remains identical - so does the geometry around the barium cation (Figure 7). However, the $\mathrm{Ba}-\mathrm{I}$ distances are elongated and the $\mathrm{Ba}-\mathrm{O}$ bond lengths shortened compared to $\mathbf{6}$, and the I-Ba-I angle is also far from linear. These differences may be explained by the large difference in bulk of the two O-ligands which results in stronger steric repulsions.

Dissolving $\mathrm{SrI}_{2}$ or $\mathrm{BaI}_{2}$ in triglyme $\left(\mathrm{CH}_{3} \mathrm{O}\left(\mathrm{CH}_{2} \mathrm{O}\right)_{3} \mathrm{CH}_{3}\right)$, only afforded the compounds $\left[\mathrm{MI}(\text { triglyme })_{2}\right] \mathrm{I}(\mathrm{M}=\mathrm{Sr} 7, \mathrm{Ba}$

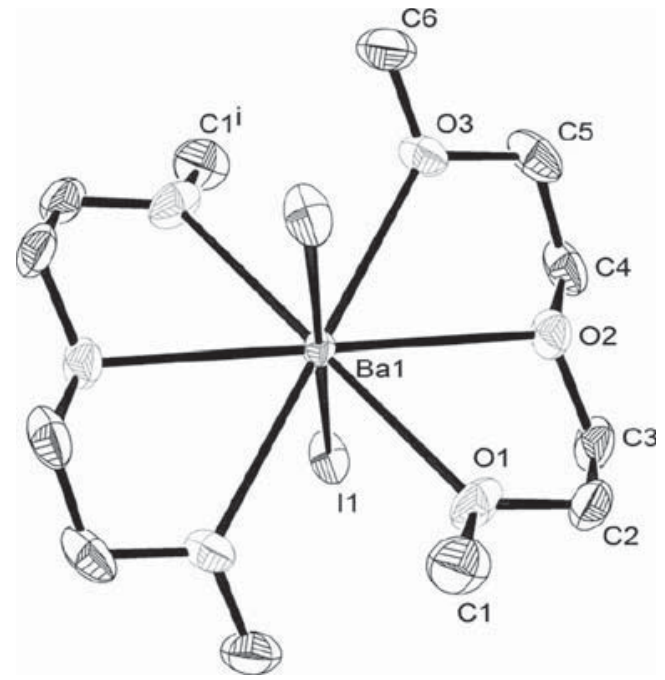

Figure 6. View of the molecular structure of molecule A in 6, hydrogen atoms are omitted for clarity, $30 \%$ probability.

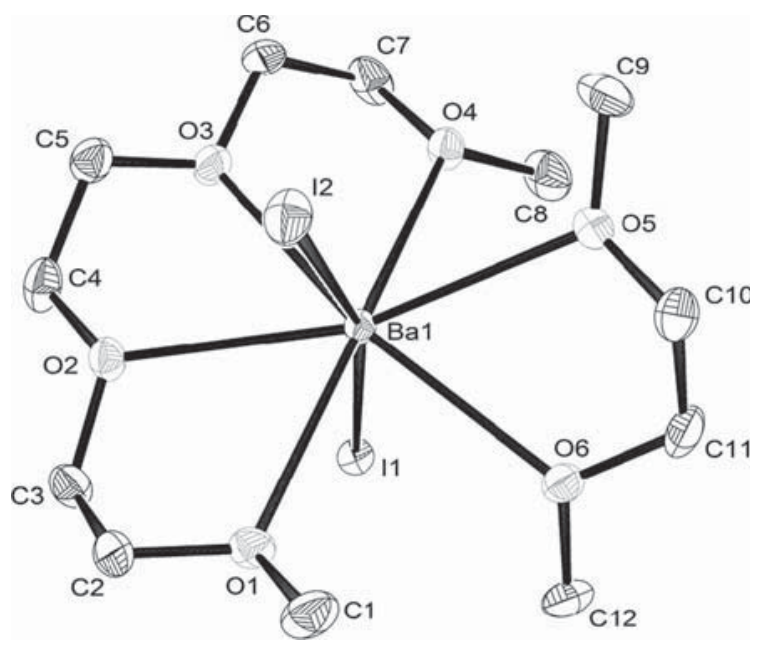

Figure 7. View of the molecular structure of trans-[BaI $(\mathrm{dme})($ triglyme)], hydrogen atoms are omitted for clarity, $30 \%$ probability.

8). A comparison of the triglyme adducts $\mathbf{7}$ and $\mathbf{8}$ is given in Table 3.

Table 3. Comparison of bond lengths and angles of triglyme adducts $\mathbf{7}$ and $\mathbf{8}$.

\begin{tabular}{lll}
\hline Compound & $\mathbf{7}$ & $\mathbf{8}$ \\
\hline $\mathrm{M}-\mathrm{I} / \AA$ & $3.485(4)$ & $3.534(3)$ \\
$\mathrm{M}-\mathrm{O} / \AA$ (av) & $2.662(3)$ & $2.814(6)$ \\
$\mathrm{O}-\mathrm{M}-\mathrm{O} /{ }^{\circ}$ (av) & $61.13(5)$ & $58.48(2)$ \\
\hline
\end{tabular}

The structure of both compounds is reminiscent of the calcium compounds $\mathbf{1}$ and $\mathbf{4}$ in so far as it is built up from a cationic unit (consisting of a metal cation to which one iodide and two O-donor ligands are bonded) and a separate iodide as counter ion (Figure 8 and Figure 9). Whereas for strontium, the trans-compound $\mathbf{2}$ in DME is afforded and in diglyme the cis-conformation is preferred (5), the triglyme ligands seem to be too large to be accommodated together with two iodide 
anions in the coordination sphere. This effect is also observed for the barium compound $\mathbf{8}$, and both cations reach thus a coordination number nine. Their coordination geometry can roughly be described as a distorted tricapped trigonal prism. For 7, two oxygen atoms of one ligand and one oxygen atom of the other triglyme ligand form each triangular face $(\mathrm{O} 1, \mathrm{O} 2$, $\mathrm{O} 5$ and respectively $\mathrm{O} 4, \mathrm{O} 7, \mathrm{O} 8)$. The iodide anion and the last oxygen atom of each triglyme ligand (O3 and O6) cap the three square faces of the prism.
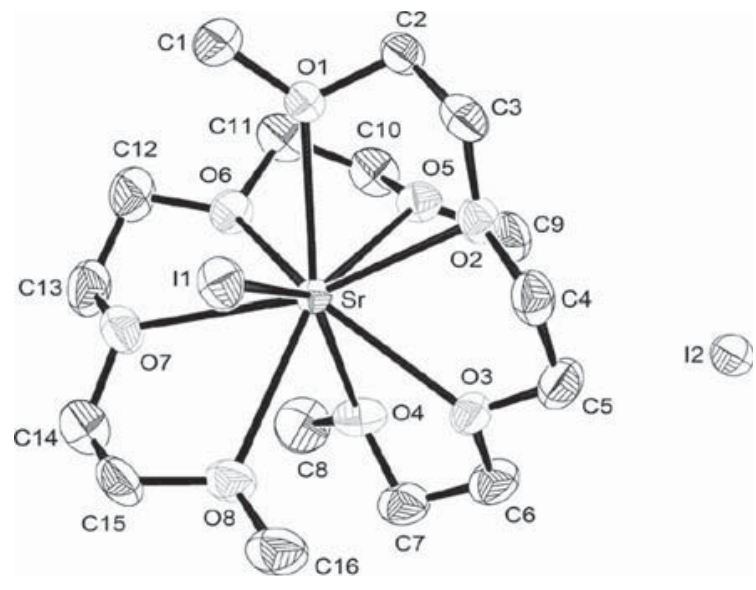

Figure 8. View of the molecular structure of 7, hydrogen atoms are omitted for clarity, $30 \%$ probability.

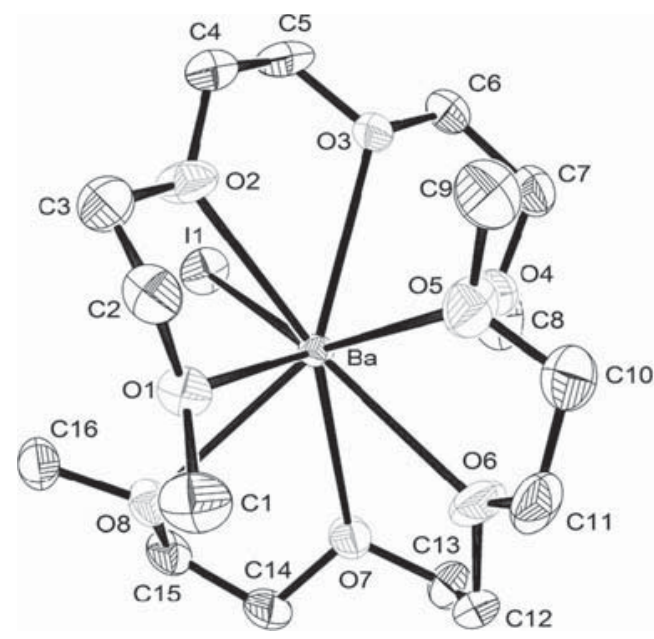

Figure 9. View of the molecular structure of $\mathbf{8}$, hydrogen atoms are omitted for clarity, $30 \%$ probability.

In $\mathbf{8}$, the first trigonal face is formed by three oxygen atoms of one triglyme ligand (06, O7, O8), the second one by the last oxygen atom of this ligand and two oxygen atoms of the other triglyme ligand $(\mathrm{O} 2, \mathrm{O} 3, \mathrm{O} 5)$. The first and the last oxygenatoms of the second triglyme ligand (O1 and $\mathrm{O} 4)$ and the iodide ion cap the three square faces of the prism.

The fact that the coordination number becomes larger in 7 and $\mathbf{8}$, makes that the $\mathrm{M}-\mathrm{X}(\mathrm{X}=\mathrm{O}, \mathrm{I})$ bond lengths logically longer on average compared to distances observed in previous molecular compounds $\mathbf{2}$ and $\mathbf{5}$ for strontium, and $\mathbf{3}$ and $\mathbf{6}$ for barium. The $\mathrm{Sr}-\mathrm{O}$ bonds vary between 2.614(3) and 2.717(5) $\AA$ and the bite $\mathrm{O}-\mathrm{Sr}-\mathrm{O}$ angles of triglyme ligands vary be- tween 59.98(6) and 63.91(9) ${ }^{\circ}$. The $\mathrm{Sr}-\mathrm{I}$ bond at 3.485(4) $\AA$ in 7 is by $0.1 \AA$ and $0.16 \AA$ larger than the $\mathrm{Sr}-\mathrm{I}$ distances observed in $\mathbf{2}$ and $\mathbf{5}$ respectively. This gives a cationic species, the counter ion $\mathrm{I} 2$ not being bonded at all to the cationic unit since all further Sr.*I contacts are larger than $6.43 \AA$. An analogue to 7 with pseudo-halides is $\left[\mathrm{Sr}\left(\mathrm{NO}_{3}\right)(\mathrm{EO} 3)_{2}\right]\left(\mathrm{NO}_{3}\right)(\mathrm{EO} 3$ $=$ triethylene glycol) ${ }^{[20]}$ where one anion is directly bonded to the cation whereas the other is weakly linked via hydrogen bonds to an $\mathrm{OH}$ group of one of the polyglycols. Regarding $\mathbf{8}$, the compound cis-[BaI $(\mathrm{dme})($ tetraglyme $)]^{[9]}$ is the only known adduct presenting similar coordinating ligands. Even if both compounds present the same coordination number, the introduction of one smaller and one larger ligand (DME and tetraglyme) instead of two identical triglyme ligands allows the coordination of the two iodide ions in cis-position. The $\mathrm{Ba}-\mathrm{O}$ bonds vary between 2.777(7) and 2.867(5) $\AA$ and the bite $\mathrm{O}-\mathrm{Ba}-\mathrm{O}$ angles of triglyme ligands vary between $56.92(3)$ and $60.56(2)^{\circ}$. The Ba-I bond length at 3.534(3) $\AA$ is much longer than the $\mathrm{Ba}-\mathrm{I}$ distances observed in $\mathbf{3}$ and $\mathbf{6}$. This $\mathrm{Ba}-$ I distance bond length is generally observed for $\mu$-bridging iodide anion, not for terminal ligand. This gives a cationic species, the counter ion $\mathrm{I} 2$ not being bonded at all to the cationic unit since all further Ba‥I contacts are larger than $6.60 \AA$. Replacing triglyme by tetraglyme leads to the ionic species $\left.[\text { Ba(tetraglyme })_{2}\right] \mathrm{I}_{2},{ }^{[9]}$ in which none of the iodide ions remains in the coordination sphere of the cation.

As often observed due to Schlenk equilibrium and already reported, alkaline earth metal iodides in presence of bidentate and bulkier polydentate O-donors form very stable species. The chelating nature of the glyme ligands tends to shield the cations very well and saturate their coordination spheres, which results in a loss of reactivity. We wanted to see if the introduction of a more labile THF molecule induces enhancement of the reactivity, opening the coordination sphere of the metal complex. Thus, mixtures of dried and distilled THF and ethereal ligands (DME and diglyme) in different ratios were prepared and added to $\mathrm{MI}_{2}(\mathrm{M}=\mathrm{Ca}, \mathrm{Sr}, \mathrm{Ba})$. Some have been obtained and characterized, namely trans- $\left[\mathrm{CaI}_{2}(\mathrm{dme})_{2}(\mathrm{thf})\right] \quad(9),{ }^{[10]}$ trans$\left[\mathrm{SrI}_{2}(\mathrm{dme})_{2}(\mathrm{thf})\right](\mathbf{1 0})$, trans- $\left[\mathrm{BaI}_{2}(\mathrm{dme})_{2}(\mathrm{thf})\right](\mathbf{1 1})$, and trans$\left.\left[\mathrm{CaI}_{2} \text { (diglyme)(thf }\right)_{2}\right](\mathbf{1 2}) ;{ }^{[11]}$ their solid state structures are described below. A comparison of the DME/THF adducts $\mathbf{9}, \mathbf{1 0}$, and $\mathbf{1 1}$ and the diglyme/THF adduct $\mathbf{1 2}$ is given in Table 4 .

Redistribution reactions between $\mathrm{O}$-donor solvents are common with organo-alkaline earth metal compounds. For instance, Westerhausen and co-workers described the recrystallization of [(1-naphthyl)Ca(thf $\left.)_{4}\right] \mathrm{I}_{2}$ from DME leading to the formation of trans- $\left[\mathrm{CaI}_{2}(\mathrm{dme})_{2}(\mathrm{thf})\right] \cdot{ }^{[10]}$ Similarly, the reaction of $\mathrm{CaI}_{2}$ with a 1:1 mixture of DME and THF leads also to the crystallization of the compound trans- $\left[\mathrm{CaI}_{2}(\mathrm{dme})_{2}(\mathrm{thf})\right](9)$ in high yield and purity. The same coordination number and geometry as for the trans- $\left[\mathrm{MI}_{2}(\text { thf })_{5}\right]$ adducts $\left(\mathrm{M}=\mathrm{Sr},{ }^{[6]} \mathrm{Ba}^{[7]}\right)$, trans-[CaI ${ }_{2}($ diglyme $\left.)(\mathrm{dme})\right],{ }^{[12]} \mathbf{1}$ and $\mathbf{4}$ are observed: seven and a pentagonal bipyramid (Figure 10).

However, with the smaller calcium atom, the geometry does not fit that well the almost perfect pentagonal bipyramid of the THF compounds anymore, but resembles more a very distorted one as observed in the trans- $\left[\mathrm{CaI}_{2}(\operatorname{diglyme})(\mathrm{dme})\right] \operatorname{adduct}^{[12]}$ 
Table 4. Comparison of bond lengths and angles of the glyme/THF adducts $\mathbf{9 , 1 0 , 1 1}$ and $\mathbf{1 2}$.

\begin{tabular}{|c|c|c|c|c|}
\hline Compound & 9 & 10 & 11 & 12 \\
\hline M-I /Å (av) & $3.134(2)$ & $3.253(5)$ & $3.448(3)$ & $3.119(5)$ \\
\hline $\mathrm{I}-\mathrm{M}-\mathrm{I} /{ }^{\circ}$ & $179.09(2)$ & $178.64(4)$ & $154.90(1)$ & $175.62(3)$ \\
\hline M-O /Å (glyme) (av) & $2.485(8)$ & $2.609(5)$ & $2.803(5)$ & $2.486(3)$ \\
\hline $\mathrm{M}-\mathrm{O} / \AA$ (THF) (av) & $2.384(2)$ & $2.515(4)$ & $2.763(3)$ & $2.424(2)$ \\
\hline $\mathrm{O}-\mathrm{M}-\mathrm{O} /{ }^{\circ}$ (glyme) (av) & $67.42(6)$ & $64.66(5)$ & $58.33(9)$ & $66.23(5)$ \\
\hline
\end{tabular}

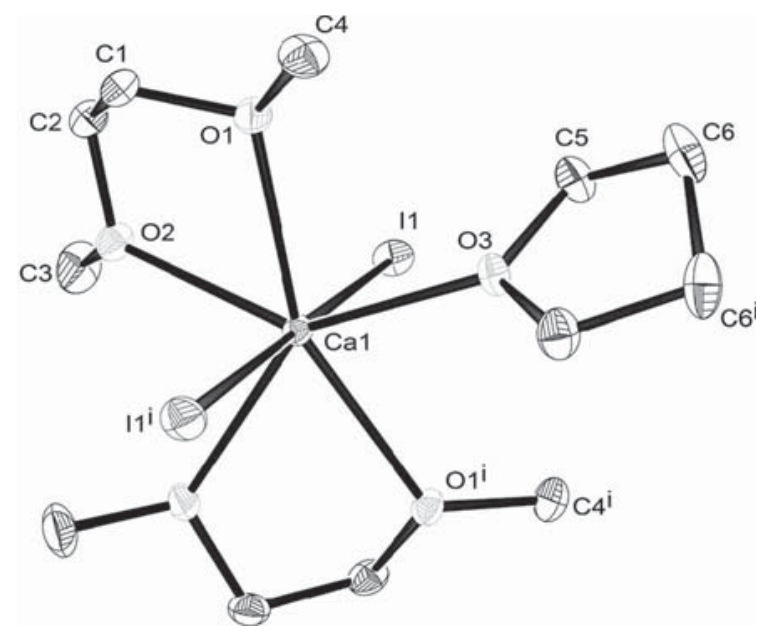

Figure 10. View of the molecular structure of $\mathbf{9}$, hydrogen atoms are omitted for clarity, $30 \%$ probability.

(Figure 11). The $\mathrm{Ca}-\mathrm{I}$ bond lengths and $\mathrm{I}-\mathrm{Ca}-\mathrm{I}$ bond angle with values of 3.134 (2) $\AA$ and $179.09(2)^{\circ}$ are longer, respectively larger than the ones observed in trans- $\left[\mathrm{CaI}_{2}\right.$ (diglyme) (dme)] $\left(3.114(1) ; 176.52(3)^{\circ}\right)$. The $\mathrm{Ca}-\mathrm{O}$ bonds vary from 2.384(2) to 2.5092(16) $\AA$, the shortest being the $\mathrm{Ca}-\mathrm{O}$ (THF). The $\mathrm{Ca}-\mathrm{O}(\mathrm{DME})$ distances correspond well to those observed in $\mathbf{1}$, while the $\mathrm{Ca}-\mathrm{O}(\mathrm{THF})$ bond length is relatively longer than the $\mathrm{Ca}-\mathrm{O}$ (THF) in trans- $\left[\mathrm{CaI}_{2}(\text { thf })_{4}\right] .{ }^{[5]}$ The $\mathrm{O}-\mathrm{Ca}-\mathrm{O}$ angles of neighboring oxygen atoms vary considerably from the ideal value of $72^{\circ}$ with values at $67.42(6)^{\circ}$ (bite angle of DME ligands), $76.34(8)^{\circ}$ (angle between DME molecules) and 77.01(4) ${ }^{\circ}$ (angles between DME and THF). Compared to the pure DME adduct $\left[\mathrm{CaI}(\mathrm{dme})_{3}\right] \mathrm{I}(\mathbf{1}),{ }^{[13]}$ one of the three bidentate DME ligands has been replaced by one monodentate THF molecule, the missing oxygen being replaced by the second iodide anion leading no more to a separate ion-pair compound.

Following the same procedure with $\mathrm{SrI}_{2}$, only the compound trans $-\left[\mathrm{SrI}_{2}(\mathrm{dme})_{2}(\mathrm{thf})\right](\mathbf{1 0})$ is obtained. In its structure (Figure 12), the strontium cation is surrounded, as for $\mathbf{9}$, by two DME ligands and one THF molecule as O-donor ligands and two iodide anions. The structure can also be described as a distorted pentagonal bipyramid, the two iodide anions being in axial positions with $\mathrm{Sr}-\mathrm{I}$ bond lengths of 3.253(5) $\AA$. These distances are slightly longer than those observed in $\left[\mathrm{SrI}_{2}(\mathrm{thf})_{5}\right],{ }^{[6]}$ but shorter than the ones observed in $\left[\mathrm{SrI}_{2}\left(\mathrm{HOCH}_{3}\right)_{3}(\mathrm{TMEDA})\right]\left(\mathrm{TMEDA}=\mathrm{Me}_{2} \mathrm{NCH}_{2} \mathrm{CH}_{2} \mathrm{NMe}_{2}\right),{ }^{[21]}$ compounds with the same coordination number seven. They are relatively smaller than those observed in $\mathbf{2}$, due to its lower coordination number (eight in 2 ). The $\mathrm{Sr}-\mathrm{O}$ bond lengths vary between $2.515(5)$ and 2.634(5) $\AA$, the shortest being the $\mathrm{Sr}-$

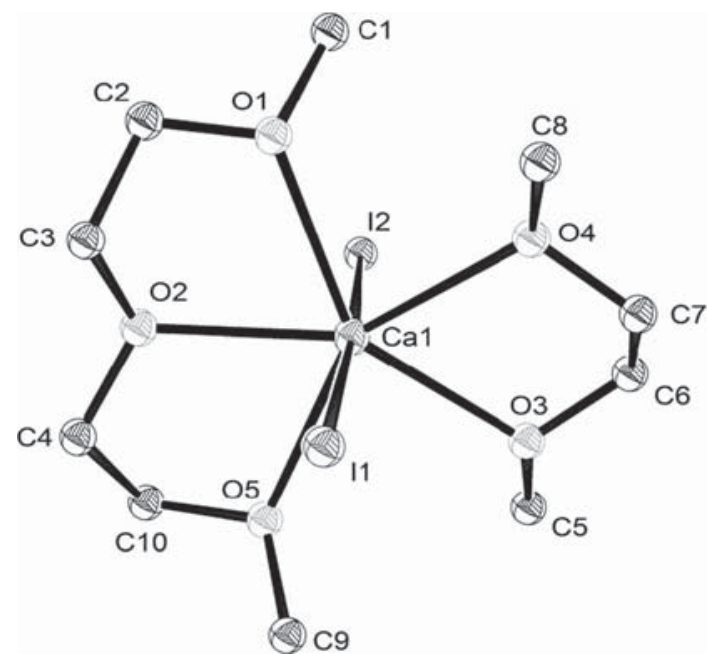

Figure 11. View of the molecular structure of $\left[\mathrm{CaI}_{2}(\mathrm{diglyme})(\mathrm{dme})\right]$, hydrogen atoms are omitted for clarity, $30 \%$ probability.

$\mathrm{O}$ (THF), and are smaller than the $\mathrm{Sr}-\mathrm{O}$ distances observed in $\mathbf{2}, \mathbf{5}, \mathbf{7}$ due to a lower coordination number (CN7), but correspond well with those in $\left[\mathrm{SrI}_{2}(\mathrm{thf})_{5}\right]{ }^{[6]}$ As 9, the geometry does not fit that well the almost perfect pentagonal bipyramid of the pure THF-compounds $\left[\mathrm{SrI}_{2}(\mathrm{thf})_{5}\right]^{[6]}$ and $\left[\mathrm{BaI}_{2}(\mathrm{thf})_{5}\right]^{[7]}$ The $\mathrm{O}-\mathrm{Sr}-\mathrm{O}$ angles of neighboring oxygen atoms vary considerably from the ideal value of $72^{\circ}$ with values at $64.66(5)^{\circ}$ (bite angle of DME ligands), 77.95(6) (angle between DME and THF ligands) and 79.49(1) (angle between DME ligands). Compared to $\mathbf{2}$, the $\mathrm{I}-\mathrm{Sr}-\mathrm{I}$ angle is much more linear with a value of $178.64(4)^{\circ}$, probably due to the decrease of the steric repulsions between the $\mathrm{O}$-donor ligands with a lower coordination number (seven in $\mathbf{1 0}$ instead of eight in 2). This I-Sr-I angle is very similar to those observed in trans- $\left[\mathrm{MI}_{2}(\text { thf })_{5}\right](\mathrm{M}$ $\left.=\mathrm{Sr},{ }^{[6]} \mathrm{Ba}^{[7]}\right),\left[\mathrm{CaI}_{2} \text { (diglyme) }(\text { dme })\right]^{[12]}$ and $\mathbf{9}$.

Some divalent rare earth metal complexes with mixture of ethereal ligands, namely THF and DME have been reported, among of them trans- $\left[\mathrm{SmI}_{2}(\mathrm{dme})_{2}(\mathrm{thf})\right]$ and trans- $\left[\mathrm{SmI}_{2}(\mathrm{dme})\right.$ $\left.(\text { thf })_{3}\right] \cdot{ }^{[22]}$ The former compound has an isomorphic structure to $\mathbf{1 0}$ as well as a similar synthetic procedure, but it was not possible to isolate the latter compound.

When $\mathrm{BaI}_{2}$ is used, the trans- $\left[\mathrm{BaI}_{2}(\mathrm{dme})_{2}(\mathrm{thf})_{2}\right](\mathbf{1 1})$ is isolated. With a coordination number of eight, the coordination sphere of the barium cation in the complex $\mathbf{1 1}$ can be described as a distorted hexagonal bipyramid (Figure 13).

The Ba-I bond lengths with 3.448(3) $\AA$ are consistent with values observed in trans- $\left[\mathrm{BaI}_{2}(\mathrm{dme})(\text { triglyme) }]^{[9]}\right.$ but smaller than those observed in other eight coordinated molecular barium adducts $^{[18 b, 18 c]}$ including 3 . They are however longer than the 


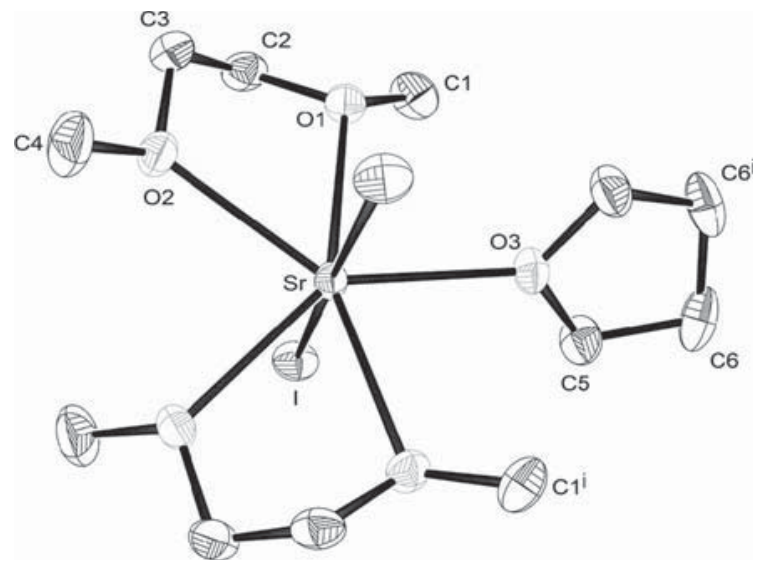

Figure 12. View of the molecular structure of $\mathbf{1 0}$, hydrogen atoms are omitted for clarity, $30 \%$ probability.

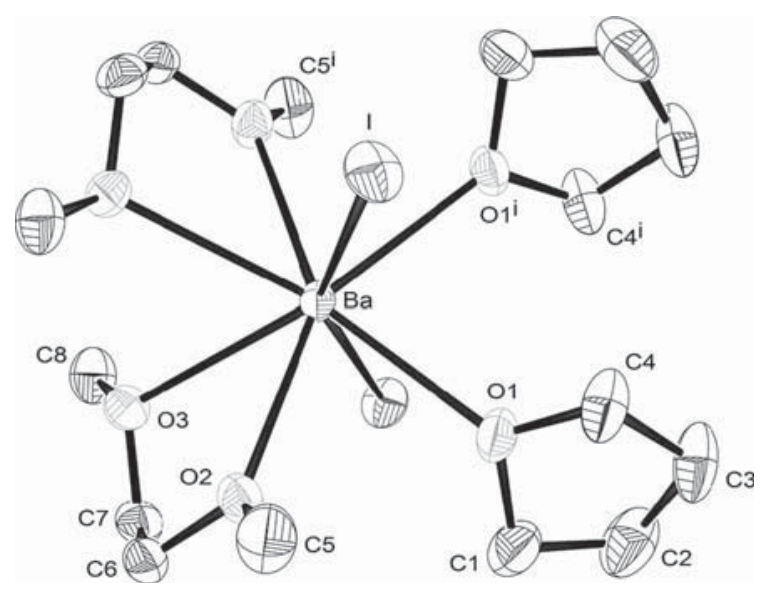

Figure 13. View of the molecular structure of 11, hydrogen atoms are omitted for clarity, $30 \%$ probability.

Ba-I distances in 6, due to the entropic effect of smaller ligands, diglyme ligands in $\mathbf{6}$ have less degrees of freedom as cited before and thus, repulsions between these ligands are smaller. They are also longer than $\mathrm{Ba}-\mathrm{I}$ distances in trans- $\left[\mathrm{BaI}_{2}(\mathrm{thf})_{5}\right]^{[7]}$ due to a larger coordination number. The I-Ba-I angle, with a value of $154.90(1)^{\circ}$ is very far from linear as observed in the trans- $\left[\mathrm{BaI}_{2}(\mathrm{dme})_{3}\right]$ compound $\mathbf{3}$ and the trans- $\left[\mathrm{BaI}_{2}(\text { diglyme })_{2}\right]$ compound 6, but is similar to the one observed in the trans[SrI $\left.{ }_{2}(\mathrm{dme})_{3}\right]$, compound 2 , and is $10^{\circ}$ lower than the one observed in trans-[ $\mathrm{BaI}_{2}(\mathrm{dme})$ (triglyme) $] .{ }^{[9]}$ This is probably due to steric repulsions between the four ethereal ligands, the two DME ligands shielding one side of the barium cation, the other side being shielded by the two THF molecules.

As discussed above, for an equal number of oxygen atoms, larger ligands are less sterically demanding than smaller one. These O-donor ligands are coordinated to the barium cation with $\mathrm{Ba}-\mathrm{O}$ distances ranging between 2.755(3) and 2.852(3) A. In 11, contrary to the other mixed-ethereal ligand adducts 9 and 10, the $\mathrm{Ba}-\mathrm{O}$ (thf) bond lengths are not the shortest ones with $\mathrm{Ba}-\mathrm{O}(\mathrm{thf})=2.763(3) \AA$ on average. These distances are longer than those observed in the compound trans- $\left[\mathrm{BaI}_{2}\left(\mathrm{thf}_{5}\right)_{5}\right]^{[7]}$ and correspond well with $\mathrm{Ba}-\mathrm{O}$ bonds lengths in $\mathbf{3}$ and $\mathbf{6}$. The $\mathrm{O}-$
$\mathrm{Ba}-\mathrm{O}$ angles in $\mathbf{1 1}$ vary from $58.33(9)^{\circ}$ (bite angle of the DME ligands), $68.77(1)^{\circ}$ (angle between DME and THF ligands) to a very large angle of $79.43(1)^{\circ}$ for the $\mathrm{O}(\mathrm{THF})-\mathrm{Ba}-\mathrm{O}(\mathrm{OTHF})$.

The recrystallization of $\mathrm{CaI}_{2}$ in a $1: 1$ mixture of freshly dried and distilled diglyme and THF affords the compound trans- $\left.\left[\mathrm{CaI}_{2} \text { (diglyme)(thf) }\right)_{2}\right] \mathbf{1 2}$ (Figure 14). This compound has already been reported by Westerhausen and co-workers in the redistribution reactions of $\left[(1\right.$-naphthyl $\left.) \mathrm{Ca}(\text { thf })_{4}\right] \mathrm{I}_{2}$ in diglyme. ${ }^{[11]}$ In 12, the Ca-I bond lengths of 3.1182(7) and $3.1208(7) \AA$ and the I-Ca-I bond angle of $175.62(3)^{\circ}$ are only slightly shorter, respectively lower than values observed in trans- $\left[\mathrm{CaI}_{2}(\text { diglyme })(\mathrm{dme})\right]^{[12]}$ and 9. As described above for $\mathbf{1}$ and $\mathbf{4}$ (and respectively $\mathbf{2}$ and 5, 3 and 7), small polyether molecules (such as THF) can easily be replaced by larger ones, DME for instance, without changes in the structure as long as the number of oxygen atoms remains constant. But what happened when larger ligands are replaced by smaller ones? The coordination spheres of $\mathbf{1 2}$ and trans- $\left[\mathrm{CaI}_{2}\right.$ (diglyme)(dme)] are very similar with only the formal substitution of the two THF molecules in $\mathbf{1 2}$ by one larger DME ligand in trans- $\left[\mathrm{CaI}_{2}(\mathrm{dig}-\right.$ lyme)(dme)]. In both compounds, the $\mathrm{Ca}-\mathrm{O}$ bonds in average are similar $(\mathrm{Ca}-\mathrm{O}=2.461(4) \AA$ in 12). Usually, the coordination number of seven in the form of a pentagonal bipyramid is observed with distortion, at least one oxygen atom being out of the mean plane formed by the oxygen atoms of the ligands. This is observed in compounds trans- $\left[\mathrm{CaI}_{2}\right.$ (diglyme)(dme)] and $\mathbf{9}$, but not in 12. In 12, all oxygen atoms of the ligands, as well as the calcium cation, are in the same plane, no distortion is observed probably due to higher degrees of freedom for THF ligands. On the other hand, the $\mathrm{O}-\mathrm{Ca}-\mathrm{O}$ angles in 12 vary considerably from the ideal value of $72^{\circ}$ with values comprised between 65.52(9) (one of the bite angles of the diglyme ligand) and $78.84(9)^{\circ}$ (angle between O4(thf) and O3(diglyme)).

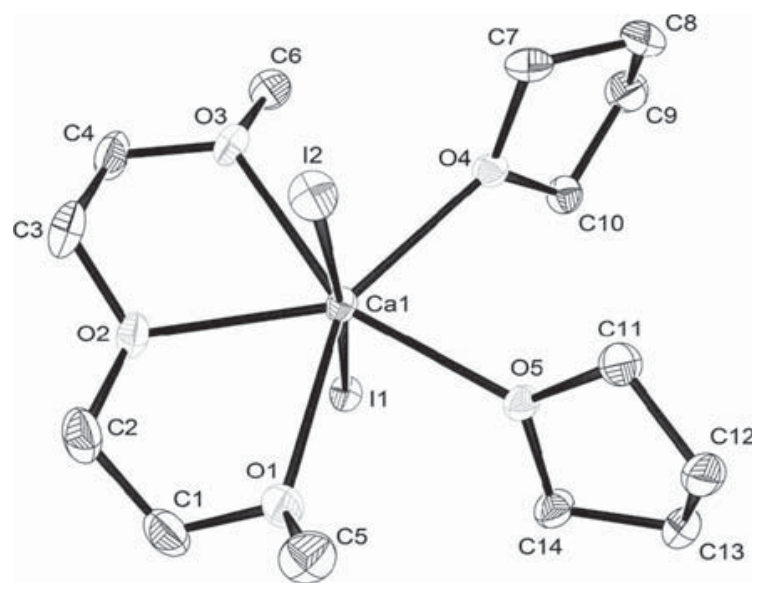

Figure 14. View of the molecular structure of 12, hydrogen atoms are omitted for clarity, $30 \%$ probability.

\section{Discussion of Reactivity}

A comparative study on the reactivity of the species 9-12 has been undertaken in order to evaluate whether the introduction of labile THF molecule(s) in the coordination sphere of 
the alkaline earth metal iodide adducts could improve their reactivity compared to the homoligand species $\mathbf{1 - 8}$. First, it has to be noted that all compounds $\mathbf{1 - 1 2}$, are monomeric in the solid-state. Indeed, in their crystal packing no I $\cdots H$ contacts shorter than $3 \AA$ are observed, only very weak O $\cdots H$ (approx. $3 \AA$ ) interactions in compounds 2, 5, 7 and $\mathbf{1 1}$ may be identified but are too weak to consider polymeric structures.

Whereas the homoligand adducts 1-8 are stable and unreactive species towards group I alkoxides or organo-alkali reagents, results show that the THF-mixed ligand adducts 9-12 present at least comparable reactivity than the pure THF-adducts. For example, reactions of trans- $\left[\mathrm{CaI}_{2}(\mathrm{thf})_{4}\right]^{[5]}$ or the adduct trans- $\left[\mathrm{CaI}_{2}(\mathrm{dme})_{2}(\mathrm{thf})\right]$ (9) with $\mathrm{LiO} t \mathrm{Bu}$ or $\mathrm{LiOPh}$ lead respectively to the products $\left[\mathrm{ICa}(\mathrm{O} t \mathrm{Bu})_{4}\{\mathrm{Li}(\mathrm{thf})\}_{4}(\mathrm{OH})\right]$ or $\left[\mathrm{CaLi}_{6}(\mathrm{OPh})_{8}(\mathrm{thf})_{6}\right] \cdot{ }^{[23,24]}$ However, in the former case, while a large excess of the reagent $\mathrm{LiO} t \mathrm{Bu}$ is required to react with the adduct trans- $\left[\mathrm{CaI}_{2}(\mathrm{thf})_{4}\right]$ to ensure the formation of the mixed-metal cluster $\left[\mathrm{ICa}(\mathrm{O} t \mathrm{Bu})_{4}\{\mathrm{Li}(\text { thf })\}_{4}(\mathrm{OH})\right]$; with $\mathbf{9}$, only four equivalents are sufficient. However, the presence of the polydentate glymes ligands (DME or diglyme) in adducts 9 12 does not influence the coordination sphere of the metal ions in the resulting complexes. Changes were only observed after recrystallization of THF- containing products in glymes, when e.g. two molecules of a $\mathrm{Li}_{6} \mathrm{Ca}$-compound are transformed into a $\mathrm{Li}_{2} \mathrm{Ca}_{2}$-derivative, setting free LiOR. ${ }^{[23,24]}$ Similar behavior is observed for the THF-mixed ligand derivatives of the heavier alkaline earth metals strontium and barium. Reactions in THF of either trans- $\left[\mathrm{MI}_{2}(\mathrm{thf})_{5}\right](\mathrm{M}=\mathrm{Sr}, \mathrm{Ba})$ or $\mathbf{1 0}-\mathbf{1 1}$ with $\mathrm{LiO} t \mathrm{Bu}$, respectively $\mathrm{LiOPh}$ lead to the mixed-metal clusters $\left[\mathrm{IM}(\mathrm{O} t \mathrm{Bu})_{4}\{\mathrm{Li}(\mathrm{thf})\}_{4}(\mathrm{OH})\right]$, respectively $\left[\mathrm{MLi}_{6}(\mathrm{OPh})_{8}(\mathrm{thf})_{6}\right]$ $(\mathrm{M}=\mathrm{Sr}, \mathrm{Ba}){ }^{[23]}$

\section{Conclusions}

We synthesized a series of homo- and mixed-polyether adducts of the heavier alkaline earth metal halides, using DME, diglyme and triglyme as well as mixtures of THF and, DME or diglyme. While for the homo-polyether adducts 1-8, there is a strong relationship between the size of the ligands and the ionic radii of the metals on the nature of the adducts (cis or trans, neutral or ionic compounds), the presence of THF allows the stabilization of the trans and neutral mixed-polyether adducts 9-12. Furthermore, the homoligand adducts 1-8 are stable species (as often observed in redistribution reactions) and do not show any further reactivity due to the strong coordination (chelate effect) of only polydentate O-Lewis base donor ligands. Compound 1, 4, 7 and $\mathbf{8}$ are rare examples of cationic species in which a cationic complex is paired with a separate anion. On the contrary, the mixed-ligand species 9-12, with the presence of the monodentate ligand (THF) are all neutral adducts. Moreover, the lability of THF allows the formation of as reactive complexes as the well-known THF-adducts.

\section{Experimental Section}

General: All reactions were carried out under argon using Schlenk tubes and vacuum line techniques. Anhydrous $\mathrm{AeI}_{2}(\mathrm{Ae}=\mathrm{Ca}, \mathrm{Sr}, \mathrm{Ba})$ or hydrated $\mathrm{AeI}_{2} \cdot \mathrm{nH}_{2} \mathrm{O}$ were purchased from Aldrich and dried under vacuum for half an hour at $300{ }^{\circ} \mathrm{C}$ in order to remove residual amounts of free iodine and water. Solvents, THF and glymes $\mathrm{MeO}\left(\mathrm{CH}_{2} \mathrm{CH}_{2} \mathrm{O}\right)_{n} \mathrm{Me}$ ( $n=1$ (DME), 2 (diglyme), 3 (triglyme)), were dried and distilled over sodium/benzophenone ketyl prior to use. IR spectra were carried out on a Perkin-Elmer Spectrum One IR spectrometer on CsI plates in Nujol or acquired on a Shimadzu FTIR8400S spectrometer equipped with Golden Gate ATR (attenuated total reflection) system.

Elemental analyses for compounds 1-12 are uncorrected. For 1-3 and 9-12, crystals easily liberate thf or dme molecules and decompose when they stay not in contact with the mother liquor, whereas for 4 $\mathbf{8}$, crystals are difficult to dry due to the high boiling point of diglyme and triglyme.

[CaI(dme) $)_{3}$ II (1): $\mathrm{CaI}_{2}(0.245 \mathrm{~g}, 0.83 \mathrm{mmol})$ was dissolved in dried DME $(30 \mathrm{~mL})$ whilst heating to reflux for $15 \mathrm{~min}$ under magnetic stirring. The solution was filtered while hot, and colorless single-crystals of $\mathbf{1}$ formed within one day at room temperature. Out of the mother liquor, crystals quickly lose solvent, as can be observed under the microscope, where they turn from clear colorless to opaque. The yield has therefore been estimated at $70 \%$ with reference to $\mathrm{CaI}_{2}$. The low evaporation temperature of DME can explain the values found for elemental analysis, where values are generally too low. Anal Calcd C 25.54, H 5.36; Found C 21.47, H $4.90 \%$; IR (nujol, CsI plates, $\mathrm{cm}^{-1}$ ): $v=2059(\mathrm{w}), 1915(\mathrm{w}), 1622(\mathrm{~m}), 1465(\mathrm{Nujol}), 1374$ (Nujol), 1285(s), 1247(s), 1192(s), 1123(w, sh), 937(w), 863 (Nujol), 859(vs), 721(Nujol), 569(m), 387(s).

Trans-[SrI $\left.\mathbf{S}_{\mathbf{2}}(\mathbf{d m e})_{3}\right] \mathbf{( 2 )}: \mathrm{SrI}_{2}(0.345 \mathrm{~g}, 1.01 \mathrm{mmol})$ was dissolved in DME $(30 \mathrm{~mL})$ by heating to reflux for $10 \mathrm{~min}$. The solution was filtered while hot, and colorless single-crystals of $\mathbf{2}$ formed within two days at $-25^{\circ} \mathrm{C}$. The yield has therefore been estimated at $74 \%$ with reference to $\mathrm{SrI}_{2}$. Anal. Calcd C 23.56, H 4.94; Found C 18.51, H $3.89 \%$ (same behavior as 1: loss of one DME molecule); IR $\left(\mathrm{cm}^{-1}\right)$ : $v=2825(\mathrm{w}), 1610(\mathrm{~m}), 1447(\mathrm{~m}), 1235(\mathrm{~m}), 1136(\mathrm{~m}), 1192(\mathrm{~s}), 1101(\mathrm{~m})$, 1052(vs), 1016(w), 854(vs), 826(m), 532(vs), 419(s).

Trans-[BaI $\left.\mathbf{B}_{2}(\mathbf{d m e})_{3}\right] \mathbf{( 3 )}: \mathrm{BaI}_{2}(0.401 \mathrm{~g}, 1.02 \mathrm{mmol})$ was dissolved in DME (40 $\mathrm{mL}$ ) by heating to reflux for $15 \mathrm{~min}$. The solution was filtered while hot, and colorless single-crystals of $\mathbf{3}$ formed within one day at $-25^{\circ} \mathrm{C}$. Out of the mother liquor, crystals quickly lost solvent, as can be observed under the microscope, where they turn from clear colorless to opaque. The yield has therefore been estimated at $68 \%$ with reference to $\mathrm{BaI}_{2}$. Anal. Calcd. C 21.79, H 4.57; Found C 18.29, H $3.88 \%$ (same behavior as 1); IR $\left(\mathrm{cm}^{-1}\right)$ : $v=1280(\mathrm{~m}), 1250(\mathrm{~m})$, 1116(w), 1066(m), 854(s), 552(m), 469(s), 412(m).

[CaI(diglyme) $)_{2}$ I (4): $\mathrm{CaI}_{2}(0.310 \mathrm{~g}, 1.05 \mathrm{mmol})$ was dissolved in diglyme $(30 \mathrm{~mL})$ by heating to reflux. The solution was filtered while hot and was then left to stand at room temperature. After one week, colorless single crystals grew at room temperature in $29 \%$ yield with respect to $\mathrm{CaI}_{2}$. Anal. Calcd C 25.64, H 5.02; Found C 25.31, H $4.93 \%$; IR $\left(\mathrm{cm}^{-1}\right): v=2833(\mathrm{~m}), 1610(\mathrm{~m}), 1454(\mathrm{~m}), 1094(\mathrm{~s}), 1052(\mathrm{~s})$, 1009(s), 861(m), 840(m), 535(s), 527(m), 464(s), 431(m).

Cis-[SrI (diglyme $\left._{2}\right]$ (5): $\operatorname{SrI}_{2}(0.174 \mathrm{~g}, 0.51 \mathrm{mmol})$ was dissolved in diglyme $(30 \mathrm{~mL})$ followed by heating to reflux under magnetic stirring. Since not all of the solid had dissolved, the solution was filtered while hot and was then left to stand at room temperature. After two days, colorless single-crystals grew in $78 \%$ yield with respect to $\mathrm{SrI}_{2}$. Anal. Calcd C 23.64, H 4.63; Found C 25.97, H 5.27\%; The differences between found and calculated values are due to the solvent, which 
remained on the crystals as they coudn't be dried under vacuum, and decomposed rapidly if left in air. IR (nujol, CsI plates, $\mathrm{cm}^{-1}$ ): $v=2849$ (Nujol), 2077(w), 1971(w), 1939(w), 1605, 1459(Nujol), 1380(m), 1354(Nujol), 1286(m), 1269(w), 1249(vs), 1203(vs), 1129(s, sh), 944(m), 870(s), 839(s), 723(Nujol), 559(s), 489(w), 461(m), 367(w).

Trans-[BaI $\mathbf{~}_{\mathbf{2}}$ (diglyme) $)_{2}$ (6): $\mathrm{BaI}_{2}(0.418 \mathrm{~g}, 1.07 \mathrm{mmol})$ was dissolved in diglyme $(40 \mathrm{~mL})$, followed by heating to reflux. The solution was filtered while hot and was then left to stand at room temperature. After two days, colorless single crystals grew in a $62 \%$ yield with respect to $\mathrm{BaI}_{2}$. Anal. Calcd C 21.77, H 4.57; Found C 20.83, H 4.29\%; IR $\left(\mathrm{cm}^{-1}\right): v=2840(\mathrm{~m}), 1650(\mathrm{~m}), 1915(\mathrm{w}), 1457(\mathrm{w}), 1285(\mathrm{~s}), 1085(\mathrm{~s})$, 1064(s), 868(m), 571(s), 481(w), 456(m), 340(w).

[SrI(triglyme $)_{2}$ ]I (7): $\mathrm{SrI}_{2}(0.382 \mathrm{~g}, 1.12 \mathrm{mmol})$ was dissolved in triglyme $(50 \mathrm{~mL})$, followed by heating to reflux until complete dissolution of $\mathrm{SrI}_{2}$. The solution was then left to stand at room temperature. After one week, colorless single-crystals grew in a $61 \%$ yield with respect to $\mathrm{SrI}_{2}$. The differences between found and calculated values are due to the solvent, which remained on the crystals as they couldn't be dried under vacuum, and decomposed rapidly if left in air. Anal. Calcd C 27.51, H 5.24; Found C 29.87, H 6.02\%; IR $\left(\mathrm{cm}^{-1}\right): v=2036(\mathrm{~m})$, 1910(w), 1622(m), 1268(s), 1239(s), 1152(s), 923(w), 856(vs), 485(s), 460(m), 423(m) 424(m).

[BaI(triglyme $)_{2}$ ]I (8): $\mathrm{BaI}_{2}(0.403 \mathrm{~g}, 1.03 \mathrm{mmol})$ was dissolved in triglyme $(50 \mathrm{~mL})$, followed by heating to reflux until complete dissolution of the $\mathrm{BaI}_{2}$. The solution was then left to stand at room temperature. After three days, colorless single-crystals grew in a $56 \%$ yield respect to $\mathrm{BaI}_{2}$. The differences between found and calculated values are due to the solvent, which remained on the crystals as they couldn't be dried under vacuum, and decomposed rapidly if left in air. Anal. Calcd C 25.71, H 4.85; Found C 31.40, H 5.76\% (same behavior as 7); IR $\left(\mathrm{cm}^{-1}\right): v=2043(\mathrm{w}), 1889(\mathrm{w}), 1620(\mathrm{~m}), 1240(\mathrm{~s}), 1186(\mathrm{~s})$, 1119(w, sh), 923(w), 861(vs), 540(s), 487(s), 438(m), 406(s)
Trans-[CaI $\mathbf{C}_{\mathbf{2}}$ (dme) $)_{\mathbf{2}}$ (thf)] (9): $\mathrm{CaI}_{2}(0.365 \mathrm{~g}, 1.24 \mathrm{mmol})$ was dissolved in a 1:1 THF-DME mixture $(40 \mathrm{~mL})$, followed by heating to reflux under magnetic stirring. At room temperature a light yellow solution was obtained from which colorless single-crystals of $\mathbf{9}$ grew overnight in a $90 \%$ yield with respect to $\mathrm{CaI}_{2}$. The low evaporation temperature of DME and THF can explain the values found for elemental analysis, where values were generally too low. Anal. Calcd C 26.39, H 5.17; Found C 23.52, H 4.79\%; IR $\left(\mathrm{cm}^{-1}\right): v=2833(\mathrm{w}), 1646(\mathrm{~m}), 1610(\mathrm{~s})$, 1440(s), 1243(m), 1193(s), 1109(s), 1052(s), 861(s), 489(m), 455(m), 437(m), 411(s).

Trans $-\left[\operatorname{SrI}_{\mathbf{2}}(\mathbf{d m e})_{\mathbf{2}}\right.$ (thf)] (10): $\operatorname{SrI}_{2}(0.39 \mathrm{~g}, 1.141 \mathrm{mmol})$ was dissolved in a 3:1 THF-DME mixture $(40 \mathrm{~mL})$ followed by heating to reflux under magnetic stirring. At room temperature a light yellow solution was obtained which was cooled at $-25{ }^{\circ} \mathrm{C}$ to give colorless singlecrystals of $\mathbf{1 0}$ within two days in a $84 \%$ yield with respect to $\mathrm{SrI}_{2}$. Anal. Calcd C 24.27, H 4.75; Found C 16.92, H 4.29\% (same behavior as 9); IR $\left(\mathrm{cm}^{-1}\right): v=2846(\mathrm{w}), 1603(\mathrm{~m}), 1454(\mathrm{~m}), 1240(\mathrm{~m}), 1119(\mathrm{~m})$, 1051(s), 863(s), 836(m), 686(w), 552(s), 540(vs), 526(w), 442(s), 430(m).

Trans-[BaI $\left.\mathbf{2}_{\mathbf{2}}(\mathbf{d m e})_{\mathbf{2}}(\mathbf{t h f})_{2}\right] \mathbf{( 1 1 )}: \mathrm{BaI}_{2}(0.43 \mathrm{~g}, 1.098 \mathrm{mmol})$ was dissolved in a 3:1 THF-DME mixture $(40 \mathrm{~mL})$, followed by heating to reflux under magnetic stirring. At room temperature a light yellow solution was obtained which was cooled at $-25^{\circ} \mathrm{C}$ to give colorless single-crystals of $\mathbf{1 1}$ within two days in a $83 \%$ yield with respect to $\mathrm{BaI}_{2}$. Anal. Calcd C 26.86, H 5.07; Found C 19.30, H 3.92\% (same behavior as 9); IR $\left(\mathrm{cm}^{-1}\right): v=2833(\mathrm{w}), 1592(\mathrm{~s}), 1451(\mathrm{~m}), 1191(\mathrm{w})$, 1112(m), 1057(s), 1024(m), 856(s), 834(m), 689(w), 534(s), 530(s), 486(m), 472(m), 452(m), 414(m).

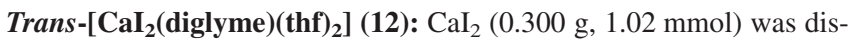
solved in a 1:1 THF-diglyme mixture $(40 \mathrm{~mL})$, followed by heating to reflux under magnetic stirring. At room temperature a light yellow solution was obtained which was cooled at $-25{ }^{\circ} \mathrm{C}$ to give colorless

Table 5. Crystallographic data and details of the crystal structure determination of the new compounds 3, 6, 7, 8, 10 and 11 .

\begin{tabular}{|c|c|c|c|c|c|c|}
\hline Compound & 3 & 6 & 7 & 8 & 10 & 11 \\
\hline Empirical formula & $\begin{array}{l}\mathrm{C}_{12} \mathrm{H}_{30} \mathrm{O}_{6} \mathrm{BaI}_{2} \\
661.50\end{array}$ & $\begin{array}{l}\mathrm{C}_{12} \mathrm{H}_{28} \mathrm{O}_{6} \mathrm{BaI}_{2} \\
659.48\end{array}$ & $\begin{array}{l}\mathrm{C}_{16} \mathrm{H}_{36} \mathrm{O}_{8} \mathrm{SrI}_{2} \\
697.87\end{array}$ & $\begin{array}{l}\mathrm{C}_{16} \mathrm{H}_{36} \mathrm{O}_{8} \mathrm{BaI}_{2} \\
747.59\end{array}$ & $\begin{array}{l}\mathrm{C}_{12} \mathrm{H}_{28} \mathrm{O}_{5} \mathrm{SrI}_{2} \\
593.76\end{array}$ & $\begin{array}{l}\mathrm{C}_{16} \mathrm{H}_{36} \mathrm{O}_{6} \mathrm{BaI}_{2} \\
715.59\end{array}$ \\
\hline Crystal system & monoclinic & triclinic & monoclinic & monoclinic & monoclinic & monoclinic \\
\hline Space group & $C 2 / c$ & $P \overline{1}$ & $P 2_{1} / c$ & $P 2_{1} / n$ & $C 2 / c$ & $C 2 / c$ \\
\hline$a / \AA ̊$ & $13.085(3)$ & $8.5881(17)$ & $9.9945(13)$ & $11.034(2)$ & $13.1009(14)$ & $15.1858(13)$ \\
\hline$b / \AA$ & $11.145(2)$ & $9.806(2)$ & $17.2690(15)$ & $17.914(4)$ & $11.4027(9)$ & $10.2936(6)$ \\
\hline$c / \AA$ & $15.767(3)$ & $13.523(3)$ & $14.9109(19)$ & $13.401(3)$ & $15.4353(17)$ & $17.3344(14)$ \\
\hline$a /^{\circ}$ & & $89.72(3)$ & & & & \\
\hline$\beta 1^{\circ}$ & $95.54(3)$ & $74.97(3)$ & $91.606(11)$ & $91.47(3)$ & $114.749(8)$ & $105.317(6)$ \\
\hline$\gamma 1^{\circ}$ & & $89.87(3)$ & & & & \\
\hline Volume $/ \AA^{3}$ & $2288.7(8)$ & $1099.9(4)$ & $2572.5(5)$ & $2647.9(9)$ & 2094.0(4) & $2613.4(3)$ \\
\hline $\mathrm{Z}$ & 8 & 2 & 4 & 4 & 4 & 4 \\
\hline Temperature /K & 203 & 203 & 203 & 203 & 203 & 203 \\
\hline$\rho_{\text {calcd. }} / \mathrm{Mg} \cdot \mathrm{m}^{-3}$ & 1.920 & 1.991 & 1.802 & 1.875 & 1.883 & 1.819 \\
\hline$F(000)$ & 1248 & 620 & 1360 & 1432 & 1136 & 1368 \\
\hline$\mu / \mathrm{mm}^{-1}$ & 4.450 & 4.630 & 4.529 & 3.864 & 5.535 & 3.905 \\
\hline $\min <\theta<\max$ & $2.80 ; 26.90$ & $2.54 ; 27.03$ & $1.80 ; 27.13$ & $2.17 ; 27.19$ & $2.47 ; 27.11$ & $2.54 ; 27.08$ \\
\hline Reflections & 7988 & 3858 & 19974 & 8838 & 7942 & 9757 \\
\hline Unique & 2315 & 3858 & 5629 & 3641 & 2255 & 2790 \\
\hline Observed & 2285 & 3858 & 3244 & 3050 & 1748 & 2648 \\
\hline Parameters refined & 100 & 198 & 248 & 249 & 95 & 117 \\
\hline GOOF & 1.353 & 1.430 & 1.037 & 1.177 & 1.120 & 1.212 \\
\hline $\mathrm{R}_{1}(\mathrm{I}>2(\sigma))$ & 0.0946 & 0.0380 & 0.0617 & 0.0437 & 0.0383 & 0.0767 \\
\hline $\mathrm{R}_{1}$ (all data) & 0.0954 & 0.0380 & 0.1238 & 0.0549 & 0.0514 & 0.0815 \\
\hline$w \mathrm{R}_{2}(\mathrm{I}>2(\sigma))$ & 0.2576 & 0.0878 & 0.1277 & 0.1233 & 0.0950 & 0.1941 \\
\hline$w \mathrm{R}_{2}$ (all data) & 0.2605 & 0.0878 & 0.1584 & 0.1290 & 0.1007 & 0.2025 \\
\hline
\end{tabular}


single-crystals of $\mathbf{1 2}$ within two days in a $\mathbf{7 3 \%}$ yield with respect to $\mathrm{CaI}_{2}$. Anal. Calcd C 29.38, H 5.28; Found C 27.16, H $4.99 \%$ (loss of one THF molecule); IR $\left(\mathrm{cm}^{-1}\right): v=2881(\mathrm{w}), 2825(\mathrm{w}), 1610(\mathrm{w})$, 1458(m), 1357(w), 1244(m), 1088(s), 1052(s), 934(m), 860(s), 835(m), 532(vs), 494(m), 447(s), 429(m), 417(m).

Single Crystal X-ray Structures: All crystals were mounted on loops and all geometric and intensity data were taken from one single crystal. Data collection using Mo- $K_{\alpha}$ radiation $(\lambda=0.71073 \AA)$ was performed at $203 \mathrm{~K}$ on a STOE IPDS-II diffractometer equipped with an Oxford Cryosystem open flow cryostat. ${ }^{[25]}$ Absorption correction was partially integrated in the data reduction procedure. ${ }^{[26]}$ The structure was solved by SIR 2004 and refined using full-matrix least-squares on $F^{2}$ with the SHELX-97 package. ${ }^{[27,28]}$ All heavy atoms could be refined anisotropically. Hydrogen atoms were introduced as fixed contributors when a residual electronic density was observed near their expected positions. Table 5 contains the crystallographic data and details of the structure analyses of compounds $3,6,7,8,10$ and 11 .

Crystallographic data for the structures $3,6,7,8,10$ and 11.have been deposited with the Cambridge Crystallographic Data Centre with the CCDC No. 875807 (3), 875447 (6), 75450 (7), 875446 (8), 875451 (10), and 875448 (11). Copies of the data can be obtained free of charge on application to CCDC, 12 Union Road, Cambridge CB21EZ, UK (Fax: +44-1223-336-033; e-mail: deposit@ccdc.cam.ac.uk).

\section{Acknowledgment}

The authors thank the Swiss National Science Foundation as well as the Universities of Basel and Fribourg for most generous support.

\section{References}

[1] a) D. C. Bradley, Adv. Inorg. Chem. Radiochem. 1972, 15, 259322 ; b) D. C. Bradley, R. C. Mehrotra, D. P. Gaur, Metal Alkoxides, AcademicPress, London 1978; c) R. C. Mehrotra, Adv. Inorg. Chem. Radiochem. 1983, 26, 269-335; d) D. C. Bradley, Chem. Rev. 1989, 89, 1317-1322; e) K. G. Caulton, L. G. HubertPfalzgraf, Chem. Rev. 1990, 90, 969-995; f) K. M. Fromm, Chem. Commun. 1999, 1659-1660; g) K. M. Fromm, E. D. Gueneau, H. Goesmann, Chem. Commun. 2000, 1783-1789; h) K. M. Fromm, Chimia 2003, 57, 175-178; i) K. M. Fromm, E. D. Gueneau, G. Bernardinelli, H. Goesmann, J. Weber, M. J. Mayor-Lopez, P. Boulet, H. Chermette, J. Am. Chem. Soc. 2003, 125, 3593-3604; j) K. M. Fromm, E. D. Gueneau, Polyhedron 2004, 23, 14791504; k) K. M. Fromm, Dalton Trans. 2006, 5103-5112; 1) W. D. Buchanan, M. A. Guino-o, K. Ruhlandt-Senge, Inorg. Chem. 2010, 49, 7144-7155.

[2] a) F. G. N. Cloke, P. B. Hitchcock, M. F. Lappert, G. A. Lawless, B. J. Royo, J. Chem. Soc., Chem. Commun. 1991, 724-726; b) J. S. Overby, T. P. Hanusa, Angew. Chem. Int. Ed. Engl. 1994, 33, 2191-2193; c) S. Harder, M. Lutz, A. W. G. Straub, Organometallics 1997, 16, 107-113; d) C. Eaborn, S. A. Hawkes, P. B. Hitchcock, J. D. Smith, Chem. Commun. 1997, 1961-1962; e) D. C. Green, U. Englich, K. Ruhlandt-Senge, Angew. Chem. Int. Ed. 1999, 38, 354-357; f) M. J. Harvey, T. P. Hanusa, V. G. Young Jr., Angew. Chem. Int. Ed. 1999, 38, 217-219; g) M. Westerhausen, M. H. Digeser, C. Guckel, H. Nöth, J. Knizek, W. Ponikwar, Organometallics 1999, 18, 2491-2496; h) M. Westerhausen, Coord. Chem. Rev. 2008, 252, 1516-1531; i) M. M. Gillett-Kunnath, J. G. MacLellan, C. M. Forsyth, P. C. Andrews,
G. B. Deacon, K. Ruhlandt-Senge, Chem. Commun. 2008, 44904492.

[3] a) S. Harder, Chem. Rev. 2010, 110, 3852-3876; b) A. Kobayashi, Y. Yamashita, Acc. Chem. Res. 2011, 44, 58-71.

[4] a) H. D. Lutz, Z. Anorg. Allg. Chem. 1967, 353, 207-215; b) H. Staeglich, E. Weiss, Chem. Ber. 1978, 111, 901-905; c) N. Y. Turova, B. A. Popovskin, A. V. Novoselova, Z. Anorg. Allg. Chem. 1969, 353, 207-215.

[5] K. F. Tesh, D. J. Burkley, T. P. Hanusa, J. Am. Chem. Soc. 1994, 116, 2409-2417.

[6] K. Ruhlandt-Senge, K. Davis, S. Dalal, U. Englich, M. O. Senge, Inorg. Chem. 1995, 34, 2587-2592.

[7] a) K. M. Fromm, Angew. Chem. 1997, 109, 2876-2878; b) K. M. Fromm, Angew. Chem. Int. Ed. 1998, 36, 2799-2801.

[8] F. Weber, G. Wolmershaeuser, H. Sitzmann, Acta Crystallogr, Sect. E 2005, 61, m512-m513.

[9] S. Mishra, L. G. Hubert-Pfalzgraf, E. Jeanneau, Polyhedron 2007, 26, 66-72

[10] M. Gärtner, H. Görls, M. Westerhausen, Acta Crystallogr., Sect. E 2007, 63, m3169.

[11] J. Langer, S. Krieck, R. Fischer, H. Görls, M. Westerhausen, Z. Anorg. Allg. Chem. 2010, 636, 1190-1198.

[12] K. M. Fromm, Cryst. Eng. Comm. 2002, 4, 318-322.

[13] K. M. Fromm, W. Maudez, Eur. J. Inorg. Chem. 2003, 34403444.

[14] W. Maudez, K. M. Fromm, 2012, Private communication to the CCDC, deposition number CCDC-876001.

[15] a) K. M. Fromm, H. Goesmann, G. Bernardinelli, Polyhedron 2000, 19, 1783-1789; b) K. M. Fromm, Chem. Eur. J. 2001, 7, 2236-2244; c) K. M. Fromm, E. D. Gueneau, A. Y. Robin, W. Maudez, J. Sague, R. Bergougnant, Z. Anorg. Allg. Chem. 2005, $631,1725-1744$.

[16] R. D. Shannon, Acta Crystallogr., Sect. A 1976, 32, 751-767.

[17] a) M. Hakansson, M. Vestergren, B. Gustafsson, G. Hilmersson, Angew. Chem. Int. Ed. 1999, 38, 2199-2201; b) T. Grob, G. Seybert, W. Massa, K. Dehnicke, Z. Anorg. Allg. Chem. 1999, 625, 1897-1903; c) T. Grob, G. Seybert, W. Massa, K. Harms, K. Dehnicke, Z. Anorg. Allg. Chem. 2000, 626, 1361-1366.

[18] a) P. C. Junk, L. M. Louis, M. K. Smith, Z. Anorg. Allg. Chem. 2002, 628, 1196-1209; b) B. W. Skelton, A. F. Waters, A. H. White, Aust. J. Chem. 1996, 49, 137-146; c) A. F. Waters, A. H. White, Aust. J. Chem. 1996, 49, 35-46.

[19] a) V. Chebolu, R. R. Whittle, A. Sen, Inorg. Chem. 1985, 24, 3082-3085; b) A. Sen, V. Chebolu, A. L. Rheingold, Inorg. Chem. 1987, 26, 1821-1823.

[20] R. D. Rogers, M. L. Jezl, C. B. Bauer, Inorg. Chem. 1994, 33, $5682-5692$

[21] A. F. Waters, A. H. White, Aust. J. Chem. 1996, 49, 87-98.

[22] W. J. Evans, T. S. Gummersheimer, J. W. Ziller, J. Am. Chem. Soc. 1995, 117, 8999-9002.

[23] W. Maudez, M. Meuwly, K. M. Fromm, Chem. Eur. J. 2007, 13, $8302-8316$

[24] W. Maudez, D. Häussinger, K. M. Fromm, Z. Anorg. Allg. Chem. 2006, 632, 2295-2298.

[25] J. Cosier, A. M. Glazer, J. Appl. Crystallogr. 1986, 19, 105-107.

[26] E. Blanc, D. Schwarzenbach, H. D. Flack, J. Appl. Crystallogr. 1991, 24, 1035-1041.

[27] M. C. Burla, R. Caliandro, M. Camalli, B. Carrozzini, G. L. Cascarano, L. De Caro, C. Giacovazzo, G. Polidori, R. Spagna, J. Appl. Crystallogr. 2005, 38, 381-388.

[28] G. M. Sheldrick, SHELX-97, Program for Crystal Structure Refinement, University of Gottingen, Germany, 1997.

Received: May 18, 2012 Published Online: August 15, 2012 